\title{
Performance and variability for yield and yield contributing characters in spring wheat
}

\author{
M. F. Ferdous, A. K. M. Shamsuddin, D. Hasna and M. M. R. Bhuiyan \\ Department of Genetics and Plant Breeding, Bangladesh Agricultural University, Mymensingh-2202, Bangladesh
}

\begin{abstract}
The present study was conducted with twenty bread wheat genotypes at the experimental field of Bangladesh Agricultural University (BAU), Mymensingh, during the period from November 2008 to March 2009 to assess performance of the genotypes, variability, heritability and genetic advance among yield and important yield contributing characters. Considering yield per plant the genotype Peacock was the best followed by BAW-1008, Pavon-76, Mayoor, Bulbul and BAW-1004. BAW-1008 was the early maturing genotype followed by Mayoor, BAW861, BAW-1004 and Balaka. BAW-970, Akbar, BAW-1004, Pavon-76, BAW-861 and BAW-1006 were semi dwarf in plant height as such they were of desired type. TP-1 and Mayoor were superior for effective tillers per plant. BAW1004 was the best genotype for spike length and grains per spike. For 100-grain weight Bulbul, for harvest index BAW-1006 was the best. Days to $90 \%$ maturity, plant height, grains per spike, 100-grain weight and harvest index exhibited high heritability. Among them grains per spike, 100-grain weight and harvest index showed high genetic advance in percentage of mean.
\end{abstract}

Keywords: Spring wheat, Variability, Heritability, Yield contributing characters

\section{Introduction}

Wheat occupies second most important cereal crop in Bangladesh on the basis of acreage and production, next to rice (BBS, 2007). Currently, total cropped land area of Bangladesh is 3,51,23,400 acres of which wheat covers an area of 9,87,960 acres (BBS, 2007). Yield of the improved cultivars is about 3 tons per hectare in farmer's field whereas in some developed countries it reaches to 8 tons per hectare (FAO, 1999).

An effective breeding programme and the effectiveness of selection depend upon the availability of genetic variation of the breeding materials. If the variability in the population is largely due to genetic cause with least environmental cause, the probability of isolating superior genotypes is high. But it is often difficult to judge as to what proportion of the observed variability is heritable (genotypic) and what proportion is non-heritable (environmental), particularly in case of characters controlled by a polygenic system. The progress of breeding in such a population is primarily conditioned by the magnitude, nature and interrelation of genotypic and environmental variation for various plant characters. It then becomes necessary to partition the observed variability into its heritable and non heritable components with the help of suitable genetic parameters such as genotypic coefficient of variation, heritability estimates, genetic advance under selection.

The present study is therefore, carried out to evaluate a collection of spring wheat germplasms and assess variation among them for yield and yield contributing traits and to study heritability and genetic advance for the traits.

\section{Materials and Methods}

The experiment was conducted at the experimental field of the Department of Genetics and Plant Breeding, Bangladesh Agricultural University (BAU), Mymensingh during the period from November 2008 to March 2009. The study included 20 genotypes of bread wheat collected from wheat germplasm collection of the Department of Genetics and Plant Breeding, Bangladesh Agricultural University (BAU), Mymensingh. 
The experiment was set in a randomized complete block design with three replications. The plot size was $2.5 \mathrm{~m} \times 1.5 \mathrm{~m}$ with plant spacing $25 \mathrm{~cm}$ between rows. The seeds were sown in rows in north-south direction. Seeds were sown in rows on the $24^{\text {th }}$ November, 2008. Different genotypes matured at different times. So harvesting was done from 08-23 march, 2009. The following data were taken from 10 randomly selected plants from each plot: days to $90 \%$ maturity, plant height, effective tillers per plant, spike length, spikelets per spike, 100 grain weight, biological yield, harvest Index and grain yield per plant.

The data were analyzed for variances and mean performance of the genotypes were tested by DMRT. Genotypic and phenotypic coefficients of variation were estimated following the formula of Singh and Chaudhury (1985). Heritability in broad sense was estimated using the formula of Johnson et al. (1955) and Hanson et al. (1956). Expected genetic advance under selection was estimated using the formula suggested by Johnson et al. (1955). Genetic advance in percent of mean was calculated by the following formula proposed by Comstock and Robinson (1952).

\section{Results and Discussion}

\section{Performances of the wheat genotypes}

The mean performance of 20 bread wheat genotypes for grain yield and different yield contributing characters were significantly varied among the genotype for all the characters. Among the genotypes BAW-1008 matured earlier followed by Mayoor, BAW-861, Akbar, BAW-1004 and Balaka. Mayoor and TP-1 produced the highest number of effective tillers per plant. For spike length, the longest spike was found in the BAW-1004 followed by BAW-861, SA-3 and SA-92. BAW-1004 produced higher number of grains per spike followed by Peacock, BAW-1008 and pavon-76. Bulbul had higher grain weight that followed by the genotypes BAW-1006, Akbar, BAW-970, BAW-1008. The genotypes BAW-1006, BAW1008, Bulbul and BAW-949 exhibited higher harvest index compared to other genotypes. The genotype Peacock was the best for grain yield. BAW-1008, Pavon-76, Mayoor, Bulbul and BAW-1004 were also high yielding genotypes on the basis of grain yield per plant. Considering most of the yield contributing traits Peacock, BAW-1008, Mayoor, BAW-1004, BAW-861, Pavon-76 and Bulbul were found promising with good yield potentials.

Table 1. Mean performances of bread wheat genotypes for yield and yield contributing characters

\begin{tabular}{|c|c|c|c|c|c|c|c|c|}
\hline Genotypes & $\begin{array}{c}\text { Days to } 90 \% \\
\text { maturity } \\
\text { (days) }\end{array}$ & $\begin{array}{l}\text { Plant } \\
\text { height } \\
(\mathrm{cm})\end{array}$ & $\begin{array}{l}\text { Effective } \\
\text { tillers per } \\
\text { plant (no.) }\end{array}$ & $\begin{array}{l}\text { Spike } \\
\text { length } \\
(\mathrm{cm})\end{array}$ & $\begin{array}{c}\text { Grains per } \\
\text { spike } \\
\text { (no.) }\end{array}$ & $\begin{array}{c}\text { 100-grain } \\
\text { weight } \\
\text { (gm) }\end{array}$ & $\begin{array}{c}\text { Harvest } \\
\text { index }\end{array}$ & $\begin{array}{c}\text { Grain yield } \\
\text { per plant } \\
(\mathrm{gm})\end{array}$ \\
\hline Pavon-76 & $111.3 c-d$ & $74.59 \mathrm{de}$ & $6.87 \mathrm{a}-\mathrm{b}$ & $9.45 \mathrm{c}-\mathrm{e}$ & $44.43 \mathrm{a}-\mathrm{c}$ & 3.07 d-h & $28.25 \mathrm{~d}-\mathrm{g}$ & $6.07 \mathrm{a}-\mathrm{c}$ \\
\hline Kav-2 & $115.3 b$ & $66.54 \mathrm{f}$ & $6.13 a-b$ & $9.02 \mathrm{e}-\mathrm{g}$ & 40.03 b-e & $2.68 \mathrm{~h}$ & 25.72 e-h & $3.93 \mathrm{f}-\mathrm{j}$ \\
\hline BAW-970 & $110.7 \mathrm{c}-\mathrm{d}$ & $78.81 \mathrm{c}-\mathrm{d}$ & $4.9 \mathrm{~d}-\mathrm{e}$ & $9.05 \mathrm{e}-\mathrm{g}$ & $31.2 \mathrm{f}-\mathrm{h}$ & $3.73 \mathrm{a}-\mathrm{d}$ & 25.92 e-h & $3.87 \mathrm{~g}-\mathrm{j}$ \\
\hline Sonalika & $115 \mathrm{~b}$ & $72.88 \mathrm{e}$ & 5.47 c-e & 9.46 c-e & $33.87 \mathrm{~d}-\mathrm{g}$ & $3.49 b-f$ & $27.34 \mathrm{~d}-\mathrm{g}$ & $4.8 c-i$ \\
\hline Akbar & 108.7 d-e & $75.3 \mathrm{~d}-\mathrm{e}$ & 5.23 c-e & 9.77 a-e & 31.57 e-h & $3.78 \mathrm{a}-\mathrm{c}$ & 29.91 c-e & $4.2 \mathrm{~d}-\mathrm{j}$ \\
\hline BAW-949 & $113.3 \mathrm{~b}-\mathrm{c}$ & $86.40 a-b$ & 5.47 c-e & $8.7 \mathrm{f}-\mathrm{g}$ & $36.97 \mathrm{c}-\mathrm{f}$ & $3.53 b-f$ & $31.79 \mathrm{a}-\mathrm{d}$ & $5.3 b-g$ \\
\hline BAW-861 & 106.3 e-f & $74.50 \mathrm{~d}-\mathrm{e}$ & 5.6 c-e & $10 a-c$ & $35.43 \mathrm{~d}-\mathrm{g}$ & $2.6 \mathrm{~h}$ & $24.63 \mathrm{f}-\mathrm{h}$ & $3.37 \mathrm{i}-\mathrm{j}$ \\
\hline SA-3 & 115.3b & $80.64 \mathrm{c}$ & $5.07 \mathrm{~d}-\mathrm{e}$ & $10.26 a-b$ & $36.47 \mathrm{c}-\mathrm{f}$ & $2.67 \mathrm{~h}$ & $21.49 \mathrm{~h}$ & $3.53 \mathrm{~h}-\mathrm{j}$ \\
\hline Mayoor & $106.3 \mathrm{e}-\mathrm{f}$ & $72.47 \mathrm{e}$ & $7.33 \mathrm{a}$ & $9.38 \mathrm{c}-\mathrm{f}$ & $34.6 \mathrm{~d}-\mathrm{g}$ & $3.25 \mathrm{c}-\mathrm{h}$ & $25.03 \mathrm{f}-\mathrm{h}$ & $5.7 \mathrm{a}-\mathrm{d}$ \\
\hline BAW-1008 & $105.3 \mathrm{f}$ & $73.32 \mathrm{e}$ & $5.13 c-e$ & 9.6 a-e & $46.07 a-b$ & 3.64 a-e & $35.23 a-b$ & $6.77 a-b$ \\
\hline TP-1 & $118.7 \mathrm{a}$ & $83.80 \mathrm{~b}-\mathrm{c}$ & $7.33 \mathrm{a}$ & $9.55 \mathrm{~b}-\mathrm{e}$ & $27.17 \mathrm{~g}-\mathrm{h}$ & $2.78 \mathrm{~g}-\mathrm{h}$ & $14.61 \mathrm{i}$ & $3.1 \mathrm{j}$ \\
\hline BAW-966 & $111.3 \mathrm{c}-\mathrm{d}$ & $73.02 \mathrm{e}$ & $5.87 \mathrm{~b}-\mathrm{e}$ & $9.31 \mathrm{c}-\mathrm{f}$ & $36.2 \mathrm{c}-\mathrm{f}$ & $3.02 \mathrm{e}-\mathrm{h}$ & $28.58 \mathrm{~d}-\mathrm{f}$ & $4.97 \mathrm{c}-\mathrm{h}$ \\
\hline Sonora-64 & $110.3 \mathrm{~d}$ & $89.75 \mathrm{a}$ & $4.83 \mathrm{e}$ & $9.06 \mathrm{e}-\mathrm{g}$ & $42.23 \mathrm{~b}-\mathrm{d}$ & $3.12 \mathrm{c}-\mathrm{h}$ & $25.38 \mathrm{f}-\mathrm{h}$ & $4.1 \mathrm{e}-\mathrm{j}$ \\
\hline Bulbul & $113.3 \mathrm{~b}-\mathrm{c}$ & $80.79 \mathrm{c}$ & $5.76 \mathrm{~b}-\mathrm{e}$ & $9.92 \mathrm{a}-\mathrm{d}$ & 32.9 e-h & $4.29 \mathrm{a}$ & $33.62 \mathrm{a}-\mathrm{c}$ & 5.53 a-e \\
\hline BAW-1004 & 106.7 e-f & $74.63 \mathrm{~d}-\mathrm{e}$ & 5.2 c-e & $10.34 \mathrm{a}$ & $51.0 \mathrm{a}$ & $3.11 \mathrm{c}-\mathrm{h}$ & 30.09 c-e & $5.47 \mathrm{a}-\mathrm{f}$ \\
\hline BAW-1006 & $110.3 \mathrm{~d}$ & $74.37 \mathrm{~d}-\mathrm{e}$ & $4.8 \mathrm{e}$ & $9.18 \mathrm{~d}-\mathrm{g}$ & $29.9 \mathrm{f}-\mathrm{h}$ & $4.13 a-b$ & $35.95 \mathrm{a}$ & $4.43 \mathrm{~d}-\mathrm{j}$ \\
\hline SA-92 & $115.3 \mathrm{~b}$ & $86.83 a-b$ & 5.33 c-e & $9.97 \mathrm{a}-\mathrm{c}$ & $41.87 \mathrm{~b}-\mathrm{d}$ & $2.67 \mathrm{~h}$ & $25.23 \mathrm{f}-\mathrm{h}$ & $4.63 c-j$ \\
\hline Peacock & $116.0 \mathrm{~b}$ & $86.33 a-b$ & $6.13 \mathrm{a}-\mathrm{d}$ & $9.52 \mathrm{~b}-\mathrm{e}$ & $47.47 a-b$ & $3.46 \mathrm{~b}-\mathrm{g}$ & 30.02 c-e & $6.93 \mathrm{a}$ \\
\hline Balaka & 106.7 e-f & $64.92 \mathrm{f}$ & $6.4 \mathrm{a}-\mathrm{c}$ & $8.55 \mathrm{~g}$ & $25.10 \mathrm{~h}$ & $2.90 \mathrm{f}-\mathrm{h}$ & $31.48 \mathrm{~b}-\mathrm{d}$ & $4.03 \mathrm{e}-\mathrm{j}$ \\
\hline Protiva & $110.7 \mathrm{c}-\mathrm{d}$ & $81.18 \mathrm{c}$ & $6.83 a-b$ & 9.7 a-e & $34.20 \mathrm{~d}-\mathrm{g}$ & 2.86 f-h & $24.02 \mathrm{~g}-\mathrm{h}$ & $4.43 \mathrm{~d}-\mathrm{j}$ \\
\hline
\end{tabular}

N.B. The mean values having same letter(s) are statistically identical 
Variability, heritability and genetic advance for yield and yield contributing characters in spring wheat

Variation and heritability for yield and yield contributing characters:

The characters grain yield per plant, grains per spike, 100-grain weight, harvest index and effective tillers per plant showed the high phenotypic coefficient of variation. These characters also exhibited considerable amount of genotypic coefficient of variation (Table 2). The characters days to $90 \%$ maturity, plant height and spike length exhibited low phenotypic and genotypic coefficients of variation. The characters days to $90 \%$ maturity, plant height, spike length, grains per spike, 100-grain weight, harvest index and grain yield per plant showed little differences between phenotypic and genotypic coefficients of variation, which suggests that the expression of these characters were less influenced by the growing environment.

The characters days to $90 \%$ maturity, plant height, grains per spike, 100-grain weight and harvest index were highly heritable (Table 2). On the other hand, effective tillers per plant, length of spike and grain yield per plant were moderately heritable. The analysis of genetic advance in percentage over mean showed that the characters grains per spike, 100-grain weight, harvest index and grain yield per plant had more than $20 \%$ expected genetic advance. Grains per spike, 100-grain weight and harvest index recorded high heritability coupled with high genetic advance suggesting that these characters were predominantly controlled by additive genes. Therefore, direct selection for grains per spike, 100-grain weight, harvest index and grain yield per plant would give good response in selection in the present materials.

Table 2. Genotypic variations, heritability and genetic advance for yield and yield contributing characters

\begin{tabular}{|l|c|c|c|c|c|}
\hline Characters & GCV (\%) & PCV (\%) & Heritability (\%) & GA & GA (\%) \\
\hline Days to 90\% maturity & 3.39 & 3.64 & 86.46 & 7.23 & 6.49 \\
\hline Plant height (cm) & 8.49 & 9.23 & 84.49 & 12.46 & 16.07 \\
\hline Effective tillers per plant (no.) & 12.34 & 16.69 & 54.66 & 1.09 & 18.84 \\
\hline Length of spike (cm) & 4.47 & 6.06 & 54.38 & 0.64 & 6.74 \\
\hline Grains/spike (no.) & 17.26 & 21.08 & 67.04 & 10.75 & 29.11 \\
\hline 100-grain weight (gm) & 13.94 & 17.87 & 60.89 & 0.73 & 22.54 \\
\hline Harvest index & 17.20 & 19.15 & 80.62 & 8.82 & 31.83 \\
\hline Grain yield per plant (gm) & 20.32 & 26.57 & 58.51 & 1.52 & 31.95 \\
\hline
\end{tabular}

\section{References}

BBS. 2007. Statistical Yearbook of Bangladesh. Bangladesh Bureau of Statistics. Statistics Division, Ministry of Planning, Govt. of the Peoples Republic of Bangladesh. P. 133.

Comstoc, R.E. and Robinson, H.F. 1952. Genetic parameters. Their estimation and significance. P.2844-291.

FAO. 1999. Food and Agriculture Organization, Rome of the United Nations. 49:68.

Fisher, R.A. 1936. The use of multiple measurements in taxonomic problems. P. 179-188.

Hanson, G.H., H.F. Robinson and R.E. Comstoc. 1956. Biometrical studies of yield in segregating populations of Lespedza. Agron. J. 48:268-272.

Johnson, H.W., Robinson, H.F. and Comstoc, R.E. 1955. Estimates of genetic and environmental variability in soybeans. 47(7): 314-318.

Singh, R.K. and Choudhury, B.D. 1985. Biometrical method in quantitative genetic analysis. Kalyani Publishers, Ludhiana, New Delhi, pp. 54-57. 